Article

\title{
Applying the Multi-Criteria Decision-Making Approach for Lawyer Selection from Law Firms' Perspective in China
}

\author{
Chin-Tsai Lin ${ }^{1}$, Ching-Chiang Yeh ${ }^{2, *}$ and Fan Ye ${ }^{1,3}$ \\ 1 Department of Business Administration, Ming Chuan University, Taipei City 111, Taiwan; \\ ctlin@mail.mcu.edu.tw (C.-T.L.); 07116246@me.mcu.edu.tw (F.Y.) \\ 2 Department of Business Administration, National Taipei University of Business, Taipei City 10051, Taiwan \\ 3 Hongxiang Holding Group, Ziwei building, 267 Haining Avenue, Haizhou street, Haining 314400, China \\ * Correspondence: ychinc@ntub.edu.tw; Tel.: +886-2-2322-6161
}

Received: 25 June 2020; Accepted: 13 August 2020; Published: 15 August 2020

check for updates

\begin{abstract}
This study proposes a novel evaluation model for lawyer selection incorporating the lawyer's backbone leadership attitude employing the hybrid multi-criteria decision-making (MCDM) approach. In the proposed approach, the lawyer's backbone leadership attitude is employed as an evaluation factor in the evaluation model for lawyer selection from law firms' perspective. In this paper, a hybrid approach based on the Delphi technique and analytic hierarchy process (AHP) is proposed to manage qualitative and quantitative criteria for selecting the best alternative lawyer for law firms in China. Finally, a law firm in China is carried out to verify the feasibility of the proposed approach. Based on the result, the backbone leadership does provide valuable information in the evaluation model for lawyer selection. The results also revealed that the proposed approach would help law firms and human resource managers to understand and develop strategies to hire a lawyer.
\end{abstract}

Keywords: lawyer selection; Delphi method; analytical hierarchy process; backbone leadership; law firm

\section{Introduction}

Hiring a qualified lawyer is crucial to the law firm. A lawyer is a representative of clients or a neutral third party, playing a vital role in society. Moreover, lawyer recruitment is the process of selecting, evaluating, and hiring lawyers for a business. Hence, lawyer selection is the complicated problem that is served as the impetus for law firms and academic studies.

However, with the lawyer selection problem, some obstacles arise. First, previous studies lack factors that influence the selection of lawyers [1]. Moreover, the vast majority of studies typically focused on the long-term customer relationship [2] and clients' service quality [1]. Moreover, the most frequently used factors are measured by private clients in these studies [3]. Finally, existing studies have focused on the views of corporate clients, rather than law firms.

Collaboration is naturally becoming more essential in today's dynamic business environment $[4,5]$. The complex and integrative nature of legal work requires professionals to bring together their specialized expertise in order to successfully serve clients. The backbone is the initiative as a whole by integrating the efforts of multiple partners working toward the same goal. The backbone organization of the leader plays another crucial function in organizational collaboration [6]. However, previous studies did not consider the issues for law firms [1-3].

Second, to select the best alternative lawyer is a type of multi-criteria decision-making (MCDM) problem. The analytical hierarchy process (AHP) is a tool in the decision-making [7-12]. Employing AHP can decompose the decision problem into several hierarchical levels, can help to make decisions 
based on the professional knowledge and experience of experts $[7,8]$. Hence, this study employs the AHP method to determine the relative influences of evaluation factors on lawyer selection problems.

To our best knowledge, the topic of lawyer selection from a law firm's perspective has yet to be properly investigated. The aim of this study proposes a novel evaluation model for lawyer selection, incorporating the lawyer's backbone leadership attitude employing the hybrid MCDM approach from the perspective of law firms. First, we derived the main factors through an extensive literature review while adopting the backbone leadership concept into the evaluation model to give a more comprehensive analysis for decision makers. Second, it provides a promising alternative for the lawyer selection model. The Delphi technique firstly confirms the evaluation factors that are used to select the best alternative. Next, we employ AHP to determine the relative weights of evaluation factors and to rank the alternatives. Finally, an empirical study to validate the effectiveness of the proposed approach, in a law firm in China, is carried out.

The remainder of this paper is organized as follows. Section 2 presents an overview of lawyer selection and the methods including Delphi, AHP, and our proposed approach in Section 3. Next, it describes the results and discussions of the case study. Finally, it offers the conclusions and further discussion.

\section{Literature Review}

\subsection{Factors Influencing Lawyer Selection}

Recruitment and selection are very important operations in human resource management. Personnel selection is the process of placement of individuals into jobs [13]. General factors pertaining to work mainly include cognitive ability, job knowledge, and job experience of the individuals in the organization [14].

The literature on lawyer selection is in its infancy and rather scant. Previous studies examining those factors that influence this topic place greater efforts targeting client satisfaction and service evaluation [1,15]. Some looking into clients' selection of lawyers do so from the viewpoints of corporate clients and not law firms. These studies highlighted the prominence of good personal relationships between corporate clients and lawyers [16,17] and the legal firms [18-22].

A few studies have examined choice factors as applied by private clients when selecting a lawyer [3,23], while others have noted that individual consumers like lawyer experience [24], competence [23], and reputation [25]. Dissimilarly, some studies place less emphasis on the price of lawyer services when making a decision [25], although studies have stated that clients might measure the quality of legal services based on lawyer fees [23]. The previous studies also note that factors such as experience and competence are not valued as much as competing factors, such as convenient office hours and location [24] as well as the physical appearance of the lawyer's office [15,23].

However, there are several problems from the previous studies. First, most studies look at the United States and the United Kingdom, and thus their results may or may not be applied to other countries. Second, choosing a lawyer is difficult, because legal services are relatively intangible [26], and the lawyer selection issue is often ambiguous, complex, or unpredictable $[23,27]$. Furthermore, law firms' selection factors for hiring lawyers cover tangible factors such as the demographic variables of the lawyer.

\subsection{Backbone Leadership}

The leadership styles can be classified into two categories, namely transactional and transformational [28]. Transactional leadership is a leadership style where founded on contingent rewards by exception, motivates followers to achieve optimal job performance from his or her subordinates [29]. Transformational leadership is a popular leadership style based on vision, generally energetic, enthusiastic, and passionate. Such leadership can inspire positive changes in followers to achieve a vision moored on objectives to work towards for all stakeholders' goals [29]. 
Backbone leadership, derives from the transformational leadership in which the vision is one of achieving moral good, trust, and moral rectitude, and the core values are those of integrity. Backbone leaders require a uniquely skilled individual who is comfortable with ambiguity and sees his or her role as building the capacity of the staff and partners to navigate complexity and adapt accordingly [30,31]. Building trust and respectful relationships is a cornerstone of coalition leadership [30,31].

There are some characteristics of effective backbone leadership: visionary, relationship builder, collaborative, focused, adaptive, charismatic, results-oriented and influential communicator, political and humble [30]. A good leader also requires the management competence, and collective impact stress the importance of high quality backbone leadership [32,33]. Such leaders require a keen sense of understanding when they are encountering the environmental change, which can be solved with existing resources and expertise, and when the deeper, more human side of adaptive changed is at play, which evokes fear, feelings of loss, and resistance [31].

Lawyers often act in the leadership role, especially in the context of law firms [23]. Moreover, their development should not only have the competences from their profession, but also have to exercise leadership style [25]. The lawyers work in uncharted territory-beyond the boundaries of clients, non-clients, and judge sectors. The study for leadership is needed to focus the integrative work these lawyers do-convening diverse stakeholders, leveraging external resources, participation, and achieving collective impact [34]. More specifically, law firms are collaborative organizations that have a team of lawyers and legal specialists who work together for their customers in order to creatively and strategically set a course for their courtroom experience.

Like most effective collaborations, law firms need a strong backbone leader to keep the work moving forward in a structured way [33]. There is a lack of studies exploring the role of backbone leadership in the law firm. This study could be the practices for lawyer selection effectively [34,35].

\subsection{Research Gap}

Regarding the above review, the previous studies lack the factors that influence the selection of lawyers. In particular, lawyer selection is a multi-criteria problem. Moreover, to the best of our knowledge, AHP has been used extensively in different evaluation problems, but has not been applied to the problem of lawyer selection so far. Ali et al. [36] and Goepel and Performance [37] provided a detailed review of the AHP methods for personnel selection-related problems, which have not been applied to the problem of lawyer selection so far.

Thus, this study endeavors to fill the gap of knowledge in lawyer selection. We propose a hybrid evaluation model for lawyer selection by integrating the Delphi and AHP techniques, while adopting lawyer's backbone leadership as an evaluation factor. First, we derive the main factor through the literature review and use the lawyer's backbone leadership attitude employed as an evaluation factor in the evaluation model from the law firms' perspective. The Delphi method is used to confirm the relevant evaluation factor. Then, we applied AHP to rank and prioritize the evaluation factors and alternative lawyers. Finally, the Chinese law firm verifies the feasibility of the proposed approach.

\section{Method}

To deal with the lawyer selection problem, a hybrid MCDM method with a combination of Delphi and AHP is proposed. The Delphi technique has proven to be a popular tool for many applications [38]. It is a useful instrument for identifying and prioritizing issues for managerial decision-making. The AHP method is a prominent and powerful tool for making decisions in MCDM problems. The principle of the AHP is to develop a hierarchy by breaking the problem down to the decision to be more manageable and easier $[7,8]$. It is a structured technique and can be the supplementary research for the Delphi method [7,8]. Moreover, the Delphi survey may be employed prior to the AHP technique to refine a set of evaluation factors.

The hybrid approach combines the relative benefits of the Delphi and AHP. Although, it can create a qualitative and quantitative measurement framework, the application of a combination of 
both techniques together for lawyer selection in China is still limited. The detail is provided in the following sub-sections.

\subsection{Delphi Method}

The Delphi technique is part of a project funded by the US Air Force [39,40]. This method entails a structured group of experts who anonymously answer questionnaires in two or more rounds [41,42]. The characteristics of the Delphi method, including controlled feedback, iteration, and anonymity and a panel of expert response, are used to elicit and refine group estimation and consensus [38].

The Delphi method consists of the literature review and interviews with experts. This method is employed because it allows for experts' interaction in the first round. The experts are able to provide further clarification on matters and present arguments to justify their opinion. The Delphi method also recognizes the evaluation factors for selecting attorneys, which we determine via anonymous interviews with professionals and from a survey of statistical outcomes regarding the topic. Hasson and Keeney [42] suggested that the number of experts, when using the Delphi method, should be between five and nine.

The experts participated in this study by placing a priority weight on each criterion via a 5-point Likert scale. Their weightings are anonymous to avoid influencing others. To form a consensus, in successive rounds, the expert team provided controlled feedback, which was distributed to each participant, by presenting each one's initial answer and the group's responses after descriptive statistical analysis. With the median and interquartile range (IQR) set by the 25th and 75th percentiles, each expert can view his/her response ahead of his/her participation in the next round. To finalize setting up a consensus, we establish that IQR should be $\leq 0.5$, and that a response rate in the range of the median \pm 1 should be greater than $80 \%$.

\subsection{Analytic Hierarchy Process (AHP)}

The well-known AHP is a systematic way for dealing with complex problems, may aid the decision maker to set priorities and then synthesize the results $[39,43,44]$. The AHP methodology in the 1970s was accomplished using the following steps [11,39,44,45].

Step 1. Define the problems.

Step 2. Set up the hierarchy structure model.

The hierarchy is built with the decision-maker's objective at the top, with the intermediate levels capturing the evaluation factors on which subsequent levels depend, and the bottom level contains the alternatives.

Step 3. Form the pair-wise comparison matrix.

Once the hierarchical structure of the AHP is built, the decision makers can systematically evaluate the alternatives by making pair-wise comparisons for each of the chosen factors. The most critical factors influencing the solution of targeted problems for the hierarchy architecture are selected. The pair-wise comparisons with respect to each decision criteria, according to a numerical scale from 1 to 9 to represent their relative importance, and are shown in Table 1.

Table 1. Table of relative scores.

\begin{tabular}{cc}
\hline Value of $a_{j k}$ & Interpretation \\
\hline 1 & $j$ and $k$ are equally important \\
\hline 3 & $j$ is slightly more important than $k$ \\
\hline 5 & $j$ is more important than $k$ \\
\hline 7 & $j$ is strongly more important than $k$ \\
\hline 9 & $j$ is absolutely more important than $k$ \\
\hline
\end{tabular}


On the other hand, if there are $n$ factors, then the pair-wise comparisons matrix as matrix $A$ :

$$
A=\left[\begin{array}{cccc}
1 & a_{12} & \ldots \ldots & a_{1 n} \\
a_{21} & 1 & \ldots \ldots & a_{2 n} \\
\cdot & . & \ldots \ldots & \cdot \\
a_{n 1} & a_{n 2} & \ldots \ldots & 1
\end{array}\right]=\left[\begin{array}{cccc}
1 & a_{12} & \ldots \ldots & a_{1 n} \\
1 / a_{12} & 1 & \ldots \ldots & a_{2 n} \\
\cdot & . & \ldots \ldots & . \\
1 / a_{1 n} & 1 / a_{2 n} & \ldots \ldots & 1
\end{array}\right]
$$

where $n$ is the number of the related elements at this level, $a_{i j}=1 / a_{j i}, a_{i j}>0$ and $a_{i j}=1 ; \mathrm{j}=1,2, \ldots, \mathrm{n}$. This requires $n(n-1) / 2$ comparisons need to be made. Moreover, each decision maker will provide an individual pair-wise comparison matrix, and then employ aggregation rules for all individual pair-wise comparison matrixes $[11,39,43,44]$. This study applied the geometric method to aggregation individual judgment comparison matrix. The geometric mean of all elements in each row of the judgment matrix $A$ is as the following equation:

$$
u_{i}=\sqrt[n]{\prod_{j=1}^{n} a_{i j}}(i, j=1, \ldots, n)
$$

Step 4. Test for consistency

The consistency test is to determine if the pair-wise comparisons have any internal conflicts. The consistency ratio (CR) checks the consistency in experts' opinions. CR is calculated in the following equation, $C R=C I / R I$, which, using the eigenvalue, $\lambda$, and corresponding number random index (RI) table, to calculate a consistency index. The RI values are presented in Table 2:

$$
\mathrm{CI}=\frac{\lambda_{\max }-n}{n-1}
$$

Table 2. Randomized index of randomization index.

\begin{tabular}{ccccccccccccccc}
\hline $\mathrm{n}$ & 3 & 4 & 5 & 6 & 7 & 8 & 9 & 10 & 11 & 12 & 13 & 14 & 15 & 16 \\
\hline $\mathrm{RI}$ & 0.525 & 0.882 & 1.115 & 1.252 & 1.341 & 1.404 & 1.452 & 1.484 & 1.513 & 1.535 & 1.555 & 1.570 & 1.583 & 1.595 \\
\hline
\end{tabular}

Consistency would only be considered reliable when the value of CR should be less than 0.1 .

Step 5. Synthesize results.

As a final step, these priorities are synthesized to obtain each alternative's overall priority, from which the alternative with the highest priority is selected.

\subsection{Proposed Approach}

In this study, we proposed the hybrid Delphi and AHP techniques for lawyer selection, as shown in Figure 1. In the first stage, the Delphi method is employed to confirm the evaluation factors. The next stage is to determine the relative weights of criteria, sub-criteria, and prioritize the alternative lawyer by the AHP method. 


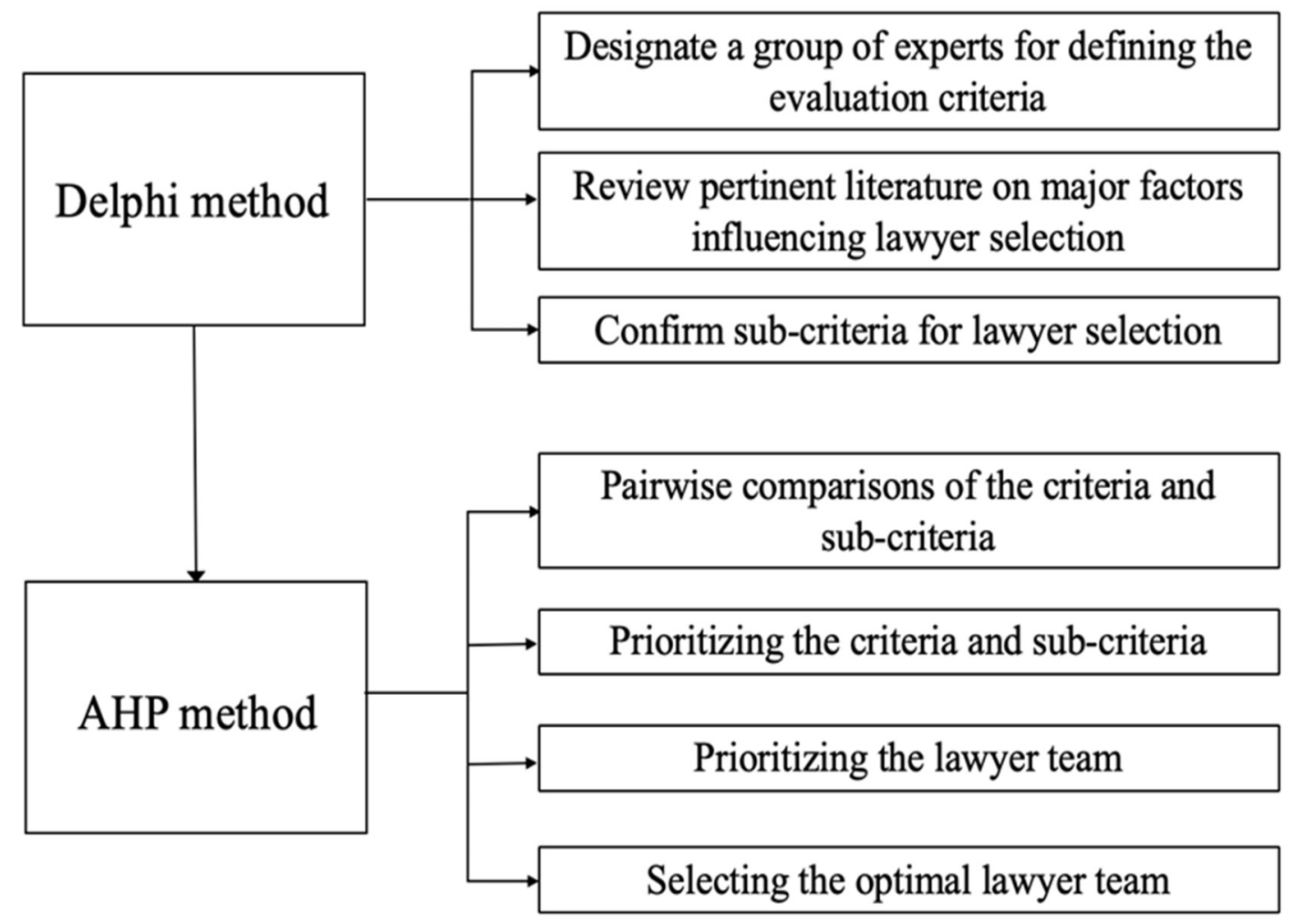

Figure 1. Framework for the proposed approach.

\subsubsection{The Survey Respondents for the Delphi and AHP}

The most critical factors in selection of expert panels are their experience and proficiency. In the study, a two-round Delphi method was employed as the group consensus is desirable. In the first round of the Delphi survey, this study conducted the expert interview with 10 senior legal practitioners who were engaged in the field of law for more than 10 years. Through their professional knowledge and work experience, they provided professional opinions and suggestions on what factors and matters needing attention should be taken into consideration in the decision-making of the law firm, with the aim of supplementing and completing the selection of the criteria and sub-criteria.

For the second round of the Delphi survey, we approached 33 experts, including 9 chief lawyers, 5 practicing lawyers, 4 original judges, 10 senior judges, and 5 law professors in China. The questionnaire was sent to each participant by e-mail to ensure independent completion of it. The same 33 experts took part in the AHP survey.

\subsubsection{The Process of Delphi and AHP Method Analysis}

First, the Delphi survey was employed with the interview of 10 experts to identify the criteria and sub-criteria for evaluating lawyer selection in China. In this study, we primarily conducted interviews with a group of participants. The expert panels were asked to evaluate the significance level of 83 pre-determined factors individually to the lawyer selection.

In the second-round Delphi analysis, the panelists gave their individual answers on these issues, i.e., first quantile, median, third quantile, and inter-quantile range (IQR) of each evaluation factor. Therefore, the results could lead to a clarified list of evaluation factors for the AHP survey. 
From the Delphi analysis, we shortlisted three criteria and their sub-criteria for further analysis. In the AHP methods, we decided to use a numerical scale between 1 and 9 (Saaty's scale) and this scale was used to assign the weights for criteria, sub-criteria, and alternatives. In the first step, the comparison was made between criteria and sub-criteria. In the next step, each alternative was compared with criteria and sub-criteria and then the overall priority weights of criteria, sub-criteria, and alternatives were calculated. Subsequently, the AHP method was employed with the Expert Choice Software (version 11) to get the weights of criteria, sub-criteria, and rank lawyer alternatives for law firms.

\section{Results and Discussion}

\subsection{Empirical Analysis}

For verifying the applicability of the proposed approach, the case of a law firm in China is carried out. As a case study, a law firm attempts to hire a lawyer from a list of three candidate lawyers, A, B, and C. The proposed approach for lawyer selection comprises the Delphi and AHP techniques. They are elaborated as below.

\subsubsection{Identification of Evaluation Factors by the Delphi Method}

In order to understand the evaluation factors of lawyer selection, we used the Delphi method to obtain expert scoring. In this study, two rounds of questionnaires were employed, as the following steps:

Step 1: The first-round Delphi result

A literature review was made before the first round of the Delphi study. In this context, 83 sub-criteria were collected through the elimination of repeating and/or similar criteria.

In the first round of the Delphi survey, the experts in the survey who were anonymous were asked to evaluate 83 sub-criteria selected from the literature, to add any other sub-criterion that they thought to be necessary, and to indicate the sub-criteria that they propose to exclude. The data were collected through individual interviews in which the questionnaires were completed by 10 experts.

Based on the feedback provided in the first round of the Delphi survey, the second questionnaire was modified accordingly. Then, the extracted factors were classified into three groups of factors, according to the experts' opinion. The criteria are as follows: professional level, backbone leadership, and practice experience.

Step 2: The second-round Delphi result

We conducted the second-round survey, final panels consisted of 33 experts. These respondents were asked to describe and score the suggested factors in terms of their significance, using a 5-point Likert scale from "very unimportant" (1 point) to "very important" (5 points). The questionnaire was sent to each participant by e-mail to ensure independent completion of it. Respondents e-mailed back the completed questionnaire within the stipulated period.

During the second-round of the Delphi method, we saw a high degree of consensus on the priorities given to the 83 criteria (IQR $\leq 0.5$, and over $80 \%$ of responses are within the range of the median value \pm 1 ) (see Tables $3-5$ ). From the 32 sub-criteria connected to the professional level (see Table 3), the results show that those with a median over 4 (more than moderately relevant) were service quality (P1), customer-oriented (P19), and professional category (P27). 
Table 3. Verified results of the professional level.

\begin{tabular}{|c|c|c|c|c|}
\hline No. & Sub-Criteria & Median & IQR & Result \\
\hline P1 & Service quality & 4.61 & 0.50 & Accepted \\
\hline $\mathrm{P} 2$ & Personal qualifications & 3.67 & 0.50 & Rejected \\
\hline P3 & Typical cases & 3.61 & 0.50 & Rejected \\
\hline $\mathrm{P} 4$ & Stability & 3.58 & 0.50 & Rejected \\
\hline P5 & Spirit of cooperation & 3.85 & 0.50 & Rejected \\
\hline P6 & Cooperation mechanism & 3.36 & 0.50 & Rejected \\
\hline P7 & Clear division and cooperation & 3.52 & 0.50 & Rejected \\
\hline P8 & Project management capability & 3.73 & 0.50 & Rejected \\
\hline P9 & Professionalism & 3.15 & 0.50 & Rejected \\
\hline P10 & Payment of service value & 3.58 & 0.50 & Rejected \\
\hline P11 & Team scaling & 3.39 & 0.50 & Rejected \\
\hline P12 & Team specialization & 3.70 & 0.50 & Rejected \\
\hline P13 & Team elite & 3.67 & 0.50 & Rejected \\
\hline P14 & Team integration & 3.82 & 0.50 & Rejected \\
\hline P15 & Self-improvement ability & 3.64 & 0.50 & Rejected \\
\hline P16 & Productivization of legal services & 3.70 & 0.50 & Rejected \\
\hline P17 & Business professional segmentation & 3.64 & 0.50 & Rejected \\
\hline P18 & Service standard processing & 3.70 & 0.50 & Rejected \\
\hline P19 & Customer-oriented & 4.18 & 0.50 & Accepted \\
\hline $\mathrm{P} 20$ & Service area & 3.58 & 0.50 & Rejected \\
\hline $\mathrm{P} 21$ & Division of cases and distribution system & 3.73 & 0.50 & Rejected \\
\hline $\mathrm{P} 22$ & Quality control system & 3.79 & 0.50 & Rejected \\
\hline $\mathrm{P} 23$ & Training system & 3.55 & 0.50 & Rejected \\
\hline $\mathrm{P} 24$ & Management and synergy system & 3.67 & 0.50 & Rejected \\
\hline $\mathrm{P} 25$ & Structural rationalization & 3.70 & 0.50 & Rejected \\
\hline P26 & Values & 3.76 & 0.50 & Rejected \\
\hline $\mathrm{P} 27$ & Professional category & 4.33 & 0.50 & Accepted \\
\hline $\mathrm{P} 28$ & Insist on taking facts as the core & 3.76 & 0.50 & Rejected \\
\hline P29 & Victory rate & 3.64 & 0.50 & Rejected \\
\hline P30 & Membership update mechanism & 3.55 & 0.50 & Rejected \\
\hline P31 & Branding of legal services & 3.55 & 0.50 & Rejected \\
\hline P32 & Total profit and per capita & 3.52 & 0.50 & Rejected \\
\hline
\end{tabular}


Table 4. Verified results of the backbone leadership.

\begin{tabular}{|c|c|c|c|c|}
\hline No. & Sub-Criteria & Median & IQR & Result \\
\hline B1 & Performance & 3.55 & 0.50 & Rejected \\
\hline B2 & Visionary & 4.45 & 0.50 & Accepted \\
\hline B3 & To engage in legal affairs in this field & 3.64 & 0.50 & Rejected \\
\hline B4 & Interoperability with external networks & 3.91 & 0.00 & Rejected \\
\hline B5 & Comprehension and investigation & 3.97 & 0.00 & Rejected \\
\hline B6 & Influential communicator & 4.21 & 0.50 & Accepted \\
\hline B7 & Integration with company business & 3.45 & 0.50 & Rejected \\
\hline B8 & Speed of response to customer needs & 3.58 & 0.50 & Rejected \\
\hline B9 & Credit to customers & 3.64 & 0.50 & Rejected \\
\hline B10 & Qualification & 3.82 & 0.50 & Rejected \\
\hline B11 & Transaction efficiency & 3.27 & 0.50 & Rejected \\
\hline B12 & Diligence and duty & 3.73 & 0.50 & Rejected \\
\hline B13 & Professional ethics & 3.76 & 0.50 & Rejected \\
\hline B14 & Industry evaluation and word-of-mouth & 3.67 & 0.50 & Rejected \\
\hline B15 & Balance ability & 3.64 & 0.50 & Rejected \\
\hline B16 & Practical experience outside the field & 3.61 & 0.50 & Rejected \\
\hline B17 & Professionalism & 3.67 & 0.50 & Rejected \\
\hline B18 & Acting as legal adviser & 3.58 & 0.50 & Rejected \\
\hline B19 & Follow-up services of agent termination & 3.70 & 0.50 & Rejected \\
\hline B20 & The level of legal theory & 3.70 & 0.50 & Rejected \\
\hline B21 & Foreign language level & 3.27 & 0.50 & Rejected \\
\hline B22 & Second degree & 3.18 & 0.00 & Rejected \\
\hline B23 & Human relationship & 3.88 & 0.50 & Rejected \\
\hline B24 & Records of rewards and punishments & 3.52 & 0.50 & Rejected \\
\hline B25 & Average cycle of case handling & 3.73 & 0.50 & Rejected \\
\hline B26 & Re-judgment rate (litigation cases) & 3.79 & 0.50 & Rejected \\
\hline B27 & Return satisfaction & 3.58 & 0.50 & Rejected \\
\hline B28 & Political competence & 3.33 & 0.50 & Rejected \\
\hline B29 & Background of law education & 3.73 & 0.50 & Rejected \\
\hline B30 & Good at learning, research, and thinking & 3.85 & 0.50 & Rejected \\
\hline B31 & Results-oriented & 4.30 & 0.50 & Accepted \\
\hline
\end{tabular}


Table 5. Verified results of the practice experience.

\begin{tabular}{lcccc}
\hline No & Sub-Criteria & Median & IQR & Result \\
\hline F1 & Credit evaluation & 4.30 & 0.50 & Accepted \\
\hline F2 & Partner cooperation & 3.73 & 0.50 & Rejected \\
\hline F3 & Reward and punishment mechanism & 3.76 & 0.50 & Rejected \\
\hline F4 & Client visibility & 4.24 & 0.50 & Accepted \\
\hline F5 & Cultural construction & 3.67 & 0.50 & Rejected \\
\hline F6 & Hardware facilities & 3.55 & 0.50 & Rejected \\
\hline F7 & Qualified as a management agent & 3.85 & 0.50 & Rejected \\
\hline F8 & Size of law firm & 3.76 & 0.50 & Rejected \\
\hline F9 & Domestic and foreign exchange mechanisms & 3.58 & 0.50 & Rejected \\
\hline F10 & Training mechanism & 3.73 & 0.50 & Rejected \\
\hline F11 & Communication skills with departments or institutions & 3.79 & 0.50 & Rejected \\
\hline F12 & Law firm rating & 3.82 & 0.50 & Rejected \\
\hline F13 & Records of rewards and punishments in the industry & 3.76 & 0.50 & Rejected \\
\hline F14 & Years of membership & 3.73 & 0.50 & Rejected \\
\hline F15 & Phe service direction of law firms & 3.45 & 0.50 & Rejected \\
\hline F16 & Development prospects & 3.67 & 0.50 & Rejected \\
\hline F17 & Website construction & 3.61 & 0.50 & Accepted \\
\hline F18 & Profitability & 3.48 & 0.50 & Rejected \\
\hline F19 & Public relations & 0.50 & Rejected \\
\hline F20 & Rejected \\
\hline & Maccess qualification & 3.58 &
\end{tabular}

Based on the above procedure, the evaluation factors are shown in Table 6. Since each factor met the median (greater than 4) and IQR (less than 0.5) level, these factors are acceptable. Finally, as shown in Table 6, there are 3 criteria, including professional level, backbone leadership, and practice experience. Moreover, this reflects that the nine important sub-criteria for lawyer selection are service quality, customer-oriented, professional category, visionary, influential communicator, results-oriented, client evaluation, client visibility, and public relation. Thus, these criteria and sub-criteria were identified and confirmed by the Delphi method and further used in the AHP model.

Table 6. Criteria refined by the experts.

\begin{tabular}{|c|c|c|}
\hline Criteria & Sub-Criteria & References \\
\hline \multirow{3}{*}{ Professional level } & Service quality & Minor [46], Crocker [47], Filler [48] \\
\hline & Customer-oriented & MacLane and Walmsley [49], Crocker [47], Minor [46] \\
\hline & Professional category & Fulero and Penrod [50], MacLane and Walmsley, [49] \\
\hline \multirow{3}{*}{ Backbone leadership } & Visionary & Turner et al. [30], Hanleybrown et al. [31] \\
\hline & Influential communicator & Turner et al. [30], Hanleybrown et al. [31] \\
\hline & Results-Oriented & Selin [6], Turner et al. [30], Hanleybrown et al. [31] \\
\hline \multirow{3}{*}{ Practice experience } & Client evaluation & Braucher et al. [51], Robertson [52] \\
\hline & Client visibility & Crocker [47], Filler [48] \\
\hline & Public relations & Rooks and Shanklin [24], Meyers and Maas [53] \\
\hline
\end{tabular}




\subsubsection{Applying AHP for Optimal Lawyer Selection}

The AHP technique consists of several steps, which are detailed below:

Step 1: Structure the hierarchy model

Based on the Delphi method contained in the previous section and interviews with the expert team, a four-level hierarchical structure was developed. As shown in Figure 2, the AHP model encompass the three criteria addressed in the above section (i.e., professional level, backbone leadership, and practice experience). Moreover, as Figure 2 depicts, a further nine sub-criteria are elaborated.

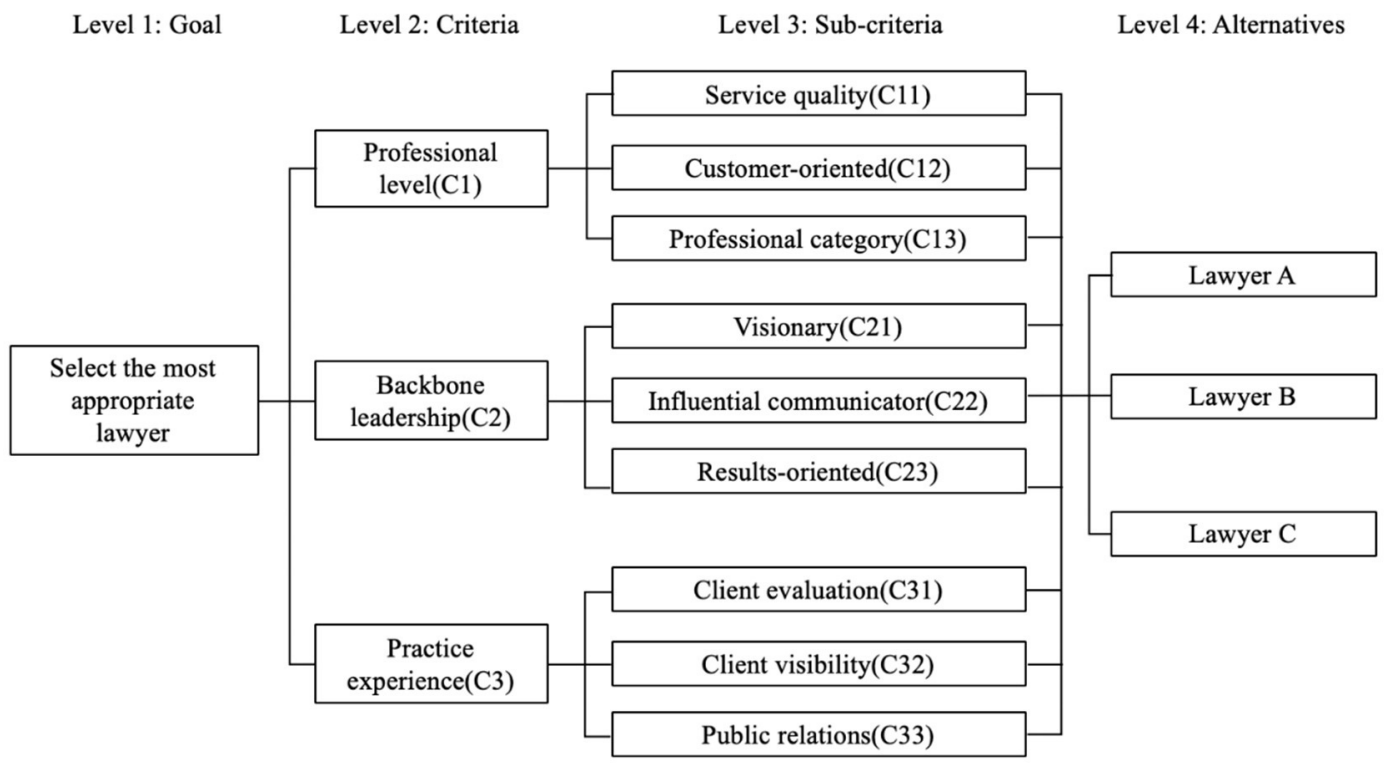

Figure 2. Framework for evaluating lawyer selection.

Step 2: Compute the pair-wise comparisons

After establishing the hierarchal model, a pair-wise comparison to express experts' preferences was conducted. After the expert team gave weighted, their geometric mean values help up formulate a standard for selecting the alternative lawyers. In this study, the Expert Choice is software that can automatically calculate the weights and synthesize the result. The results are shown in Table 7.

Table 7. Aggregate pair-wise comparison matrix for criteria of level 2.

\begin{tabular}{cccc}
\hline & Professional Level & Backbone Leadership & Practice Experience \\
\hline Professional level & 1 & 1.7470 & 1.999 \\
\hline Backbone leadership & 0.5724 & 1 & 1.747 \\
\hline Practice experience & 0.5003 & 0.5724 & 1 \\
\hline & Note: $(1) \lambda_{\max }=3.0199 ;(2) \mathrm{CR}=0.0192 \leqq 0.1$. \\
\hline
\end{tabular}

Step. 3: Perform the consistency testing

In order to ensure the consistency of the judgments, the CI and CR are analyzed. The results of the sub-criteria are shown in Table 7. As the evaluation criterion met the required levels of CR (less than 0.1), the judgments are acceptable.

Step 4: Calculate the criteria weight

The priority weight of criteria and sub-criteria are calculated along with their rank as shown in Table 8. The results reveal that professional level (C1) (0.4777) is the most important factor influencing the lawyer selection, followed by backbone leadership (C2) (0.3148), and practice experience (C3) (0.2075). 
Table 8. Weights of criteria and sub-criteria.

\begin{tabular}{|c|c|c|c|c|c|}
\hline Criteria & $\begin{array}{l}\text { Weight of } \\
\text { Criteria }\end{array}$ & Sub-Criteria & $\begin{array}{c}\text { Weight of } \\
\text { Sub-Criteria }\end{array}$ & $\begin{array}{l}\text { Overall Weight of } \\
\text { Sub-Criteria }\end{array}$ & Rank \\
\hline \multirow{3}{*}{ Professional level } & \multirow{3}{*}{$\begin{array}{c}0.4777 \\
\quad(1)\end{array}$} & Service quality & 0.3816 & 0.1823 & 1 \\
\hline & & Customer-oriented & 0.3004 & 0.1435 & 4 \\
\hline & & Professional category & 0.3180 & 0.1519 & 3 \\
\hline \multirow{3}{*}{ Backbone leadership } & \multirow{3}{*}{$\begin{array}{c}0.3148 \\
(2)\end{array}$} & Visionary & 0.4990 & 0.1589 & 2 \\
\hline & & Influential Communicator & 0.1884 & 0.0600 & 8 \\
\hline & & Results-Oriented & 0.3125 & 0.0995 & 5 \\
\hline \multirow{3}{*}{ Practice experience } & \multirow{3}{*}{$\begin{array}{c}0.2075 \\
(3)\end{array}$} & Client evaluation & 0.4088 & 0.0848 & 6 \\
\hline & & Client visibility & 0.3601 & 0.0747 & 7 \\
\hline & & Public relations & 0.2312 & 0.0480 & 9 \\
\hline
\end{tabular}

Step 5: Synthesize the results

After obtaining the weight of evaluation factors, the alternatives with respect to each criterion can be done. In Figure 2, we construct a judgment matrix taken on a quantitative scale. The overall weights and ranking of sub-criteria (see Table 8) was obtained after computing the eigenvectors and performing the consistency test. Moreover, the Expert Choice software implements the AHP which can do the rest automatically, or we manually compute the overall priority of criteria, sub-criteria, and alternatives, which are presented in Table 9. The results show the global priorities are calculated for each of the alternatives. The highest value (0.3609) corresponds to the B, followed by A (0.3391) and $C$ (0.2999). For selection purposes, the lawyers are now ranked according to their overall priorities, as follows: $B, A$, and $C$, indicating that $B$ is the best qualified lawyer to the law firm in China.

Table 9. Overall hierarchy ranking.

\begin{tabular}{cccccc}
\hline \multirow{2}{*}{ Criteria } & Sub-Criteria & $\begin{array}{c}\text { Overall Weight } \\
\text { of Sub-Criteria }\end{array}$ & A & B & C \\
\hline \multirow{3}{*}{ Professional level } & Service quality & 0.1823 & 0.4465 & 0.2016 & 0.3519 \\
& Customer-oriented & 0.1435 & 0.7092 & 0.1501 & 0.1408 \\
& Professional category & 0.1519 & 0.2024 & 0.6278 & 0.1699 \\
\hline \multirow{3}{*}{ Backbone leadership } & Visionary & 0.1589 & 0.1387 & 0.2834 & 0.5780 \\
& Influential Communicator & 0.0600 & 0.5441 & 0.2802 & 0.1757 \\
& Results-Oriented & 0.0995 & 0.1570 & 0.6884 & 0.1546 \\
\hline \multirow{2}{*}{ Practice experience } & Client evaluation & 0.0848 & 0.2102 & 0.2247 & 0.5651 \\
& Client visibility & 0.0747 & 0.1366 & 0.6435 & 0.2200 \\
& Public relations & 0.0480 & 0.5772 & 0.2356 & 0.1872 \\
\hline Synthetic weight & & & 0.3391 & 0.3609 & 0.2999 \\
\hline
\end{tabular}

\subsection{Discussion and Findings}

In the study, the relative weights of evaluation factors by hybrid Delphi and AHP methods from the law firms' perspective. First, we derive the main factor through the literature review incorporating the lawyer's backbone leadership attitude into the lawyer selection model and further confirmed by Delphi methods. The results show a wide range of evaluation feedback from the expert team on the criteria and sub-criteria (see Table 6). Second, we further confirmed the relative importance of evaluation factors (see Table 8 ) and prioritize the candidates by AHP methods (see Table 9). The findings from these issues are presented below.

\subsubsection{Results of Delphi Method}

There are two rounds of surveys by questionnaire to select the evaluation factors by the Delphi method. The experts help formulate the model and determine the potential factors. The findings 
revealed there are three criteria and nine sub-criteria identified. The results of the study also revealed the backbone leadership should provide extra information for the lawyer selection process for law firms.

\subsubsection{Results of AHP Analysis}

Based on the above results, the factors grouped together hierarchically are constructed as shown in Figure 2. The hierarchical structure comprises of four levels: evaluating the lawyer selection for law firm (Level 1), 3 criteria (Level 2), 9 sub-criteria (Level 3), and 3 alternative lawyers (Level 4).

Professional level (C1) is deemed the most important criterion for lawyer selection. In this perspective, the sub-categories differ in importance as follows: service quality (C11) (0.3816), professional category (C13) (0.3180), and customer-oriented (C12) (0.3004).

The criteria of backbone leadership (C2) also acts as the second important factor of lawyer selection. Under this perspective, visionary (C21) (0.4990) and results-oriented (C23) (0.3125) are the most important sub-criteria for lawyer selection. The last is influential communicator (C22) (0.1884). On the other hand, in the criteria of practice experience (C3), prominence goes toward client evaluation (C31) (0.4088) as the most important factor. Client visibility (C32) (0.3601) and public relation (C33) (0.2312) are given second and third priorities.

\subsection{Implications of the Study}

Previous studies did not address lawyer selection, this study proposed a two-stage approache incorporating the lawyer's backbone leadership attitude to the lawyer selection model from the law firms' perspective. After the law firm in China is carried out, three important factors for lawyer selection are identified: professional level, backbone leadership, and practice experience. The results herein serve as a reference for law firms and human resource managers to understand and develop strategies to hire more appropriate lawyers in China.

The results of our study have implications for lawyer selection. Unlike previous studies focusing on client satisfaction and service evaluation, our study proposes an evaluation framework for lawyer selection from the perspective of law firms. The findings, thus, indicated from that the law firms' viewpoint, professional level has the highest rank among evaluation factors, which shows that this criterion is an important consideration for hiring a lawyer. Its three sub-criteria are service quality, customer-oriented, and professional category. To support a high-quality professional level, we recommend that lawyers should better develop their service quality, their professional category, and be more customer-oriented.

Moreover, backbone leadership is the second important factor and provides useful information for lawyer selection. Finally, the alternative lawyer B has the highest priority in our evaluation. Based on the above analysis, it can be concluded that the proposed approach is a well alternative solution for law firm and policy makers to understand and develop strategies to hire a lawyer.

\section{Conclusions and Further Research}

Backbone leadership establishes foundations of future HRM competitiveness [30,31]. Integration of backbone leadership and HRM competitive advantages possibly could facilitate the differentiation between resources and capabilities, especially during the recruitment process for the lawyers.

The lawyer selection problem involves multiple criteria and a finite set of potential candidate alternatives, the MCDM methods can be effectively applied to solve such type of problem. As the existing studies lack the selection of attorneys from the law firms' perspective, a novel integrated lawyer selection model incorporating the lawyer's backbone leadership attitude is proposed. The main contributions are as follows. First, this study incorporates the backbone leadership factors employed as an evaluation factor in the lawyer selection process from the perspective of law firms. Based on the result, backbone leadership does provide valuable information in lawyer selection.

Second, we proposed the integration of the Delphi and AHP technique as a two stage approach for lawyer selection. In the first stage, the evaluation factors were identified through an exhaustive 
literature review and further confirmed by the Delphi method. Moreover, by applying the AHP, the relative weights of evaluation factors and prioritizing the alternative lawyers were identified. Third, the Chinese law firms are carried out to verify the proposed approach. Finally, the proposed approach is efficient in considering the lawyer's backbone leadership attitude for hiring a lawyer for law firms, and this is useful for academia and practitioners.

\subsection{Implications for Academia}

HRM responsibilities require an overlapping set of skills and competencies [13,54]. A lawyer now needs effective skills and competencies to be an excellent contributor to the law firms. The key to better hiring may be to focus more on competencies than credentials in law firms.

To the best of our knowledge, no study has been conducted on lawyer selection from the perspective of law firms. Moreover, previous studies discarded the backbone leadership factor as a tool to evaluate the lawyer selection process. By exploring the relevant literature, the main factors for lawyer selection were derived and further analyzed based on expert team' opinion utilizing the Delphi approach. The case of the Chinese law firm incorporates the backbone leadership factor into the lawyer selection. Finally, we believe the proposed approach should be an alternative for hiring a lawyer.

\subsection{Implications for Practitioners}

To recruit and select an HRM competency-based employee is an important issue [55]. For law firms with a dynamic environment, lawyer selection has become increasingly important. As such, we offer several useful implications for law firms. Backbone leadership will provide extra information in lawyer selection. Moreover, the proposed approach would help law firms and policy makers to understand and develop strategies to hire lawyers.

\subsection{Limitations and Suggestions}

This study does have some limitations. First, we consider the backbone leadership attitudes of lawyers under the evaluation and selection of lawyers. Hence, some criteria and sub-criteria might be discarded. Future studies can be conducted to testify the issue from the client's perspective. Additional comparative analysis is carried out with the larger sample to verify. Lastly, we should compare other different professions such as managers, doctors, teachers, etc.

Author Contributions: Conceptualization, C.-T.L.; Data curation, F.Y.; Methodology, F.Y.; Validation, C.-C.Y.; Writing-original draft, C.-C.Y.; Writing-review \& editing, C.-T.L.; All authors have read and agreed to the published version of the manuscript.

Funding: This research received no external funding.

Acknowledgments: The authors thank the anonymous reviewers for their suggestions which have helped make the quality and clarity of this article better.

Conflicts of Interest: The authors declare no conflict of interest.

\section{References}

1. Furnham, A.; McClelland, A.; Swami, V. The influence of person traits on lawyer selection among British adults. Gen. Pharmacol. 2012, 139, 217-229. [CrossRef] [PubMed]

2. Palihawadana, D.; Barnes, B.R. Client loyalty and defection in the corporate legal industry. Serv. Ind. J. 2004, 24, 101-114. [CrossRef]

3. Kuehl, P.G.; Ford, G.T. The Promotion of Medical and Legal Services: An Experimental Study; American Marketing Association: Chicago, IL, USA, 1977; pp. 39-44.

4. Horlings, I.; Padt, F. Leadership for sustainable regional development in rural areas: Bridging personal and institutional aspects. Sustain. Dev. 2013, 21, 413-424. [CrossRef]

5. Luu, T.T. Discretionary HR practices and employee well-being. Pers. Rev. 2019, 49, 43-66. [CrossRef] 
6. Selin, S. Elaborating the role of backbone leadership organizations in sustainable tourism development: The Monongahela River valley coalition. Sustainability 2017, 9, 1367. [CrossRef]

7. Saaty, T.L. What is the analytic hierarchy process? In Mathematical Models for Decision Support; Springer: Berlin/Heidelberg, Germany, 1988; pp. 109-121. [CrossRef]

8. Saaty, T.L. How to make a decision: The analytic hierarchy process. Interfaces 1994, 24, 19-43. [CrossRef]

9. Yeh, C.C.; Xing, M.H. Key factors influencing digital content industry in Taiwan from the triple helix perspective. Technol. Anal. Strateg. 2016, 28, 691-702. [CrossRef]

10. Koloseni, D.; Helldin, T.; Torra, V. AHP-Like Matrices and Structures-Absolute and Relative Preferences. Mathematics 2020, 8, 813. [CrossRef]

11. Chou, T.Y.; Chen, Y.T. Applying fuzzy AHP and TOPSIS method to identify key organizational capabilities. Mathematics 2020, 8, 836. [CrossRef]

12. Yeh, C.C.; Chen, Y.F. Critical success factors for adoption of 3D printing. Technol. Forecast. Soc. 2018, 132, 209-216. [CrossRef]

13. Dainty, A.R.J.; Cheng, M.-I.; Moore, D.R. Competency-based model for predicting construction project managers' performance. J. Manag. Eng. 2005, 21, 2-9. [CrossRef]

14. Vrchota, J.; Švárová, M. Comparison of decision-making skills of students and managers. Acta Univ. Agric. Silvic. Mendel. Brun. 2015, 63, 1073-1077. [CrossRef]

15. Ellis, N.; Watterson, C. Client perceptions of regional law firms and their implications for marketing management. Serv. Ind. J. 2001, 21, 100-118. [CrossRef]

16. Paik, A.; Heinz, J.P.; Southworth, A. Political lawyers: The structure of a national network. Law Soc. Inq. 2011, 36, 892-918. [CrossRef]

17. Day, E.; Barksdale, H.C., Jr. How firms select professional services. Ind. Mark. Manag. 1992, $21,85-91$. [CrossRef]

18. Clark, T. The market provision of management services, information asymmetries and service quality-some market solutions: An empirical example. Br. J. Manag. 1993, 4, 235-251. [CrossRef]

19. Maru File, K.; Cermak, D.S.; Alan Prince, R. Word-of-mouth effects in professional services buyer behaviour. Serv. Ind. J. 1994, 14, 301-314. [CrossRef]

20. Galanter, M.; Palay, T. Tournament of Lawyers: The Transformation of the Big Law Firm; University of Chicago Press: Chicago, IL, USA, 1994.

21. Gulati, R. Does familiarity breed trust? The implications of repeated ties for contractual choice in alliances. Acad. Manag. J. 1995, 38, 85-112. [CrossRef]

22. Strub, P.J.; Priest, T.B. Two patterns of establishing trust: The marijuana user. Sociol. Focus 1976, 9, $399-411$. [CrossRef]

23. Crane, F.G. Choice criteria and cue usage in selecting lawyers. J. Prof. Serv. Mark. 1989, 5, 113-122. [CrossRef]

24. Rooks, W.A., Jr.; Shanklin, W.L. Congruence: Attorney-consumer perceptions of marketing mix elements. J. Prof. Serv. Mark. 1988, 3, 189-198. [CrossRef]

25. Meyers, M.S. The importance of the Internet in the selection of service providers. In Allied Academies International Conference. Academy of Marketing Studies. Proceedings; Jordan Whitney Enterprises Inc.: North Carolina, NC, USA, 2005; Volume 10, pp. 29-32.

26. Andrus, D.M. The advertising of legal services to small business executives. J. Prof. Serv. Mark. 1995, 12, 139-161. [CrossRef]

27. Hadfield, G.K. The price of law: How the market for lawyers distorts the justice system. Mich. Law Rev. 2000, 98, 953-1006. [CrossRef]

28. Bass, B.M.; Avolio, B.J. Transformational leadership and organizational culture. Int. J. Public Adm. 1994, 17, 541-554. [CrossRef]

29. Bono, J.E.; Judge, T.A. Personality and transformational and transactional leadership: A meta-analysis. J. Appl. Psychol. 2004, 89, 901. [CrossRef]

30. Turner, S.; Merchant, K.; Kania, J.; Martin, E. Understanding the Value of Backbone Organizations in Collective Impact: Part 2. Available online: http://www.ssireview.org/blog/entry/understanding_the_value_ of_backbone_organizations_in_collective_impact_2 (accessed on 8 August 2020).

31. HanleyBrown, F.; Kania, J.; Kramer, M. Channeling Change: Making Collective Impact Work; Available online: http://www.ssireview.org/blog/entry/channeling_change_making_collective_impact_work (accessed on 8 August 2020). 
32. Fleming, A.; Kishida, M.G.; Kimmel, C.B.; Keynes, R.J. Building the backbone: The development and evolution of vertebral patterning. Development 2015, 142, 1733-1744. [CrossRef]

33. Kania, J.; Kramer, M. Collective impact. Innov. Rev. 2011, 9, 36-41.

34. Heifetz, R.A.; Linsky, M. A survival guide for leaders. Harv. Bus. Rev. 2002, 80, 65-74.

35. Heifetz, R.; Grashow, A.; Linsky, M. Leadership in a (permanent) crisis. Harv. Bus. Rev. 2009, 87, 62-69.

36. Ali, R.A.; Nikolić, M.; Zahra, A. Personnel selection using group fuzzy AHP and SAW methods. J. Eng. Manag. Compet. 2017, 7, 3-10. [CrossRef]

37. Goepel, K.D.; Performance, B. Comparison of judgment scales of the analytical hierarchy process-A new approach. Int. J. Inf. Technol. Decis. 2019, 18, 445-463. [CrossRef]

38. Rowe, G.; Wright, G. The Delphi technique as a forecasting tool: Issues and analysis. Int. J. Forecast. 1999, 15, 353-375. [CrossRef]

39. Hsu, C.W.; Yeh, C.C. Understanding the critical factors for successful M-commerce adoption. Int. J. Mob. Commun. 2018, 16, 50-62. [CrossRef]

40. Hsu, C.C.; Sandford, B.A. The Delphi technique: Making sense of consensus. Pract. Assess. Res. 2007, 12, 10. [CrossRef]

41. Duffield, C. The Delphi technique: A comparison of results obtained using two expert panels. Int. J. Nurs. Stud. 1993, 30, 227-237. [CrossRef]

42. Hasson, F.; Keeney, S. Enhancing rigour in the Delphi technique research. Technol. Forecast. Soc. 2011, 78, 1695-1704. [CrossRef]

43. Hsu, C.W.; Yeh, C.C. Understanding the factors affecting the adoption of the Internet of Things. Technol. Anal. Strateg. 2017, 29, 1089-1102. [CrossRef]

44. Shieh, L.F.; Yeh, C.C.; Lai, M.C. Critical success factors in digital publishing technology using an ANP approach. Technol. Econ. Dev. Ecol. 2016, 22, 670-684. [CrossRef]

45. Fu, H.P.; Chang, T.S.; Yeh, H.P.; Chen, Y.X. Analysis of factors influencing hospitals' implementation of a green e-procurement system using a cloud model. Int. J. Environ. Res. Public Health 2019, 16, 5137. [CrossRef]

46. Minor, M. Comparing the hispanic and non-hispanic markets: How different are they? J. Serv. Mark. 1992, 6, 29-32. [CrossRef]

47. Crocker, K.E. The influence of the amount and type of information on individuals' perception of legal services. J. Acad. Mark. Sci. 1986, 14, 18-27. [CrossRef]

48. Filler, D.M. Lawyers in the yellow pages. Law Lit. 2002, 14, 169-196. [CrossRef]

49. MacLane, C.N.; Walmsley, P.T. Reducing counterproductive work behavior through employee selection. Hum. Resour. Manag. Rev. 2010, 20, 62-72. [CrossRef]

50. Fulero, S.M.; Penrod, S.D. The myths and realities of attorney jury selection folklore and scientific jury selection: What works. Ohio NUL Rev. 1990, 17, 229-253.

51. Braucher, J.; Cohen, D.; Lawless, R.M. Race, attorney influence, and bankruptcy chapter choice. J. Empir. Leg. Stud. 2012, 9, 393-429. [CrossRef]

52. Robertson, C.B. Online reputation management in attorney regulation. Georget. J. Leg. Ethics 2016, $29,97$.

53. Meyers, M.S.; Maas, W.E. Influences in the selection of an attorney. Acad. Mark. Stud. J. 2004, 9, 41.

54. Carson, D.; Gilmore, A. SME marketing management competencies. Int. Bus. Rev. 2000, 9, 363-382. [CrossRef]

55. Gołembska, E.; Gołembski, M. A New Model of the Personnel Function Delivery in the Logistics of Polish Firms. Logistics 2020, 4, 15. [CrossRef]

(C) 2020 by the authors. Licensee MDPI, Basel, Switzerland. This article is an open access article distributed under the terms and conditions of the Creative Commons Attribution (CC BY) license (http://creativecommons.org/licenses/by/4.0/). 